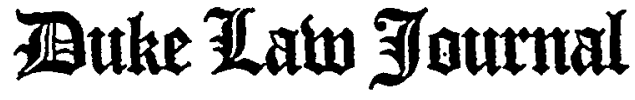

\section{THE UNIFORM COMMERCIAL CODE AND THE CHOICE OF LAW}

\author{
ROBERT J. NORDSTROM* \\ DALE B. RAMERMAN**
}

The choice of law provisions of the Uniform Commercial Code often have been criticized on the basis that they are forum oriented, so forum oriented that their constitutionality may be questionable. The authors of this article analyze the basic Code choice of law section (UCC \& 1-105) and conclude that this section need not be read with the heavy emphasis on the forum's version of the Code as suggested by some other writers. Instead, the argument is made that the Code's choice of law principles permit development in accordance with the forum's general notions of choice of law. Additionally, the Code can provide impetus for complete acceptance of party autonomy in selecting the systen of law which will govern the rights and duties of the parties to a contract.

Many law review pages have been devoted to the task of M proving that the choice of law provisions of the Uniform Commercial Code are unsound and perhaps even unconstitutional. ${ }^{1}$ Such critical analyses had their purpose when the Code was in

* A.B. 1948, Western Michigan University: J.D. 1949, University of Michigan. Professor of Law, The Ohio State University; Visiting Professor of Law, Duke University (1968-69).

** B.A. 1964, Seattle Pacific College; M.A. 1966, University of Washington; J.D. 1969, Duke University.

The authors acknowledge the aid of Dean A. Kenneth Pye and Professor Hans W. Baade (both of the School of Law, Duke University) in reviewing this article. Their many helpful criticisms were incorporated into the final draft. Unfortunately, the authors must admit that any errors remaining in this article are theirs, not those of Dean Pye or Professor Baade.

I See. e.g., Freund, Analysis of Conflict of Laws Provisions of Section 1-105, 1955 N.Y. LAW REvision Comin REP. (vol. 1) 49; Rheinstein, Conflict of Laus in the Linjorm Conmercial Code, 16 LAW \& CONTEMP. Prob. 114 (1951); Smith, Conflicts and (haos or Contract and L'niformity: the Uniform Commercial Code, 2 KA.s. L. Rev. 11 (1953); Tuchler, Bounda.ries to Party Autonomy in the Lniform Commercial Code: A Radical Vielt; II St. Louis L.J. 180 (1967). 
draft form, while there was still a chance that the language could be changed; but now that the Code is the law of the country, the time has come to take the statutory language (such as it is) and, if possible, give it a construction which both accomplishes the purpose of the draftsmen and promotes the policies underlying rational choice of law principles.

The Uniform Commercial Code has been adopted in 51 jurisdictions, and the resulting uniformity should avoid a great many of the choice of law problems which have plagued pre-Code lawyers and courts. Unfortunately, this wide-spread acceptance has not completely eliminated the need for choice of law rules in commercial transactions. No foreign nation has yet adopted the Code, and most states have altered various sections to reflect some local policy. Moreover, courts have and will continue to interpret the same Code sections differently.2 These facts add up to a not-sostartling conclusion: even though commercial transactions are regulated by a fairly uniform group of statutes in this country, international transactions and even transactions bet...en Code states will continue to generate choice of law problems.

The Code contains six sections specifically designed to aid in the solution of these problems. The basic section is contained in Article $I$ and establishes three rules:

1. For five factual patterns-transactions controlled by Code provisions dealing with rights of creditors against goods sold, bank deposits and collections, bulk transfers, investment securities, and secured transactions-the law of a particular jurisdiction is to be applied by all states. ${ }^{3}$ In general, these are situations in which a

\footnotetext{
$=$ The differing legislative and judicial treatment given to the privity problem is one area of substantive law in which the choice of law question can be determinative of the results in a particular case. Other statutory differences include: (1) the omission by Mississippi of UCC $\$ 2-316$, Miss. CODE ANiv. $\$ 4$ IA (Spec. U.C.C. Supp. 1969); (2) the omission of UCC \$ 2-302 by California, CAL. ComM. CODE $\$ 2302$ (West Supp. 1964), and North Carolina. N.C. GeN. STAT. \$ 25-2-302 (1965); (3) the increase by Oklahoma in the statutory period in UCC $\$ 2-725$ to five years, OKLA. STAT. ANN. tit. 12A. $\$ 2-725$ (1963): (4) the provision in the Colorado Code that the four-year period of limitations may not be varied by agreement, Colo. REv. Srar. A.Niv. \$ 155-2-725 (1963); and (5) the provision in the Massachusetts Code providing that there are no implied warranties in contracts to sell human blood, blood plasma. or other human tissues or organs from a blood bank or reservoir for tissue and organs, Mass. GEx. Laws Axis, ch. 106, \$2-316(5) (Supp. 1968). These are cited as illustrative, and not as limiting the number of instances in which choice of law can determine the results of the case.

= UNifory Commercial CODE $\$ 1-105(2)$ [hercinufter cited as UCC]. This section refers to five other Code sections which provide the choice of law rules for the factual patterns listed in $§ 1-105(2)$.
} 
third party is likely to become involved and in which a type of situs law can reasonably be selected as the controlling law.

2. Aside from these situations, the Code provides that the parties to a transaction are free, with some limitations, to choose which system of law will govern their rights and duties.'

3. If the parties fail to choose the applicable law and if the transaction is not one of the five mentioned above, the Code of the forum state is to be applied to transactions bearing an appropriate relation to the forum state.

It is the latter two rules, as set forth in 1-105(1), which cause difficulties of construction and application:

Except as provided hereafter in this section, when a transaction bears a reasonable relation to this state and also to another state or nation the parties may agree that the law either of this state or of such other state or nation shall govern their rights and duties. Failing such agreement this Act applies to transactions bearing an appropriate relation to this state..$^{5}$

The problems created by this provision, its relation to traditional conflict of laws rules, and suggested solutions form the subject matter of this article.

\section{The Reasonable Relation Test}

Although the wisdom of a choice of law rule which allows parties to a commercial transaction to select their governing law has been questioned, the Code's answer is clear: parties who care

\footnotetext{
UUCC \& $1-105(1)$.

$\because$ Id.

IId. (emphasis added).

- F.g.. Szold. Comments on Tentative Draft .io. 6 of the Restatement (Second). Conflict of Laus Contracts, 76 HARv. L. Rev. 1524 (1963); Weintraub, The Contracts Proposals of the Second Restatement of (onflict of Laws-A (ritique, 46 Iowa L. REv, 713 (1961). Prolessor Weintraub has attacked the wisdom of party autonomy but recognizes that "section 1-105(I) is fait accompli, and tilting at windmills, although good artery-flushing exercise, is somewhat discouraging. especially when. as here, the windmills show no sign of weakening." Weintraub, Choice of Lai" Jor Products Liability: The Impact of the L'nijorm Connercial code and Recent and Developments in Conflicts Analysis: 44 TEXAS L. REv. 1429. 1434 (1966).

for articles supporting party autonomy see Braucher, Impromptu Remarks, 76 HARV. L. REv. 1718 (1963): Ehrenzweig, Adhesion Contracts in the Conflict of Laws. 53 CoLuv. L. REv. 1072 (1953); Tuchler, Boutdaries to Party Autonomy in the Linjorm Commercial code: A Radical Viess, II ST. Lours L.J. 180 (1967): Yntema. Contract and Conflict of Laus: "Athonomy" in (hoice of Law' int the L nited States, 1 X.Y.L.F. 46 (1955).
} 
to plan with possible disputes in mind may specify which system of law will govern their rights and duties. This autonomy, however, is not unfettered. There are limitations on the transactions in which a selection may be made, on the law which may be selected, and on the persons affected by the choice. ${ }^{8}$ Moreover, any provision regarding the governing law must be agreed upon by both parties."

\section{The Need for a Reasonable Relation}

The Code permits parties to select the law which will govern their rights and duties provided that their transaction bears a "reasonable relation" to the state or nation whose law is selected.10 The inference is that if the parties choose the law of some state which has no reasonable relation to the transaction, that choice will not be recognized. There appear to be no theoretical objections to allowing the parties complete freedom of choice as to applicable law, ${ }^{11}$ just as they may bargain over any other term of their agreement. Nevertheless, the Code clearly limits their choice, perhaps to protect courts from having to apply a bizarre foreign law chosen by caprice. Such fears would seem to be misplaced, however, for given the financial implications of a commercial transaction, few contracting parties are apt to agree that their rights and duties are to be governed by a law which has no connection with their transaction.12 Further, these "built-in" limitations do not protect courts from being confronted with unfamiliar law in those instances in which the transaction does bear a reasonable relation to a foreign country.

Most of the cases in which courts will be called upon to consider the reasonable relation test of 1-105 will be fairly easy to decide. ${ }^{13}$ The situations in which parties tend to agree upon

\footnotetext{
"UCC $\$ 1-105(1)$.

9 Id.

to $I d$.

"Practical objections to an unfettered rule allowing party autonomy are suggested in W. COOK. LOGICAL ANd Legal Bases of the CONFLict Of LaWs 412-18 (1942).

12 "A court will not apply the chosen law if the parties had no reasonable basis for selecting it. The court will not. for example, apply forcign law which has been selected by the parties in the spirit of adventure or to provide mental exercise for the judge. Situations of this sort do not arise in practice. Contracts are entered into for serious purposes and rarely, if ever, will the parties choose a governing law without good reason to do so." RESTATEMENT (SECOND). CoNfLICT OF LAwS § 332a, comment $f$ (Tent. Draft No. 6, 1960).

is See. e.g., Old Colony Trust Co. v. Penrose Indus. Corp., 380 F. Supp. 698, 711 (E.D. Pa. 1968).
} 
applicable law are those in which the contacts are divided, roughly equally, between two or more jurisdictions. In such a case the parties' choice of law should be upheld if the only challenge is that the connection is not reasonable. There will, however, be a few cases, as measured by the total number of disputes, in which the state or nation whose law is chosen will have only a minimal connection with the facts of the transaction: for example, it may be only the domicile of one or both of the parties, the place from which the offer was made, the place from which the goods were shipped, the principal place of business of one or both of the parties, ${ }^{\text {it }}$ or the situs of the property sold. The question then becomes whether any one of these contacts will satisfy the "reasonable relation" test of 1-105.

With respect to this requirement the Comment to 1-105 states, in necessarily vague terms, that "[i]n general, the test of 'reasonable relation' is similar to that laid down by the Supreme Court in Seeman v. Philadelphia Warehouse Co., 274 U.S. 403, 47 S. Ct. 626, 71 L. Ed. 1123 (1927). Ordinarily the law chosen must be that of a jurisdiction where a significant enough portion of the making or performance of the contract is to occur or occurs.' "15 No one, not even the drafters of 1-105, could detail all of the factors which, in every case, will constitute a "reasonable" relation. However, the last quoted sentence, which at first appears only to substitute "significant" in place of "reasonable," may provide a guideline to aid in solving those cases in which it is asserted that the law chosen by the parties is not reasonably related to the transaction. That sentence states that the law chosen by the parties will meet the test of reasonableness if a significant portion of either the making or the performance is to occur or occurs in the chosen jurisdiction. The entire commercial transaction is to be divided into its principal components, formation and performance; and only a portion of either of these components must be significant. Consequently, even though the contact relied upon in choosing applicable law could be classified as "insignificant" when measured against all of the contacts involved in the entire commercial transaction in dispute, nevertheless, that single contact may be

\footnotetext{
"See A.S. Rampell, Inc. v. Hyster Co., 3 N.Y.2d 369, 144 N.E.2d 371, 165 N.Y.S.2d 475 (1957).

ts UCC $\$ 1-105$, Comment I.
} 
"significant" when measured against the isolated facts of the contract's making or the facts of its performance, and thus sufficient under 1-105 to justify choosing the law of that state.

The Seeman case cited in the Comment involved the question of which state's usury statute was to govern a loan transaction between a New York borrower and a Pennsylvania lender. Although the loan agreement did not contain a choice of law clause, the parties signed the notes and arranged for performance in Pennsylvania, evidently for the purpose of having that state's usury laws control (and uphold) the agreement. The Supreme Court, in applying the law apparently intended by the parties, stated that the commercial loan would be upheld if the loan was valid either at the place of making or at the place of performance. The Court added this limitation: "[T]he parties must act in good faith. . . . The effect of the qualification is merely to prevent the evasion or avoidance at will of the usury laws otherwise applicable, by the parties' entering into the contract or stipulating for its performance at a place which has no normal relation to the transaction and to whose law they would otherwise be subject." 16 ,

When the Comment reference to Seeman is combined with the statutory policy favoring party autonomy, the result is that the parties' choice should be upheld unless the transaction lacks a normal connection with the state whose law was selected. Only when it is shown that the contact did not occur in the normal course of the transaction, but was contrived to validate the parties' choice of governing law, should the relation be held unreasonable; in other cases, the clause should be upheld. ${ }^{17}$ Courts should guard against combining notions of sovereignty in choice of law with the flexibility of the Code's "reasonable relation" test to strike down the selected law-leaving the parties with an uncertainty which the Code was designed to eliminate.

One apparently simple case may cause difficulty under the

${ }^{16} 274$ U.S. at 408. Although the Seman case did not involve an explicit choice of law clause, it has been frequently cited by cases in which the validity of such a clause is in issue. See. e.g.. Consol. Jewelers, Inc. v. Standard Fin. Corp., 325 F.2d 31, 34 (6th Cir. 1963); Merchants' \& Mfgs. Sec. Co. v. Johnson, 69 F.2d 940 (8th Cir. 1934); Ury v. Jewelers Acceptance Corp.. 227 Cal. App. 2d 11, 38 Cal. Rptr. 376 (1964).

"See Restatenent (SecoNd), Conflict of Laws \$ 332a, comment f (Tent. Draft No. 6, 1960). Other readings of UCC $\$ 1-105$ are suggested in Tuchler, Boundaries to Part!' Autonom!. in the Ciniform Commercial Code: A Radical View. II ST. Louss L.J. 180 (1967). 
peculiar wording of 1-105: "... when a transaction bears a reasonable relation to this state and also to another state or nation the parties may agree that the law either of this state or of such other state or nation shall govern their rights and duties." Difficulties may arise if the transaction has no connection with the forum state but does have contacts with one or more other states. In such a case should the forum give effect to the choice of law agreement, or should it hold that the agreement is invalid simply because there was no reasonable relation to the forum? ${ }^{\text {is }}$ The answer clearly ought to be that the agreement is effective. In such a situation the forum has no interest in the outcome of the litigation; no local policy is called into play since, by hypothesis, the forum has no reasonable connection with the transaction and is providing only a situs for the suit. ${ }^{19}$ Moreover, the Code expresses a policy favoring party autonomy. If the chosen law is from a jurisdiction which has a reasonable connection with the facts of the transaction, the clause should be upheld although for this case the Code is inartfully drafted..$^{0}$ In short, section 1-105 ought to be read as the Comment suggests:

Subsection (l) states affirmatively the right of the parties to a multi-state transaction or a transaction involving foreign trade to choose their own law. That right is subject to the firm rules stated in the six subsections listed in subsection (2), and is limited to jurisdictions to which the transaction bears a "reasonable relation." "y

\footnotetext{
Ix Another alternative is open to the courts. It may dismiss the case under a doctrine of forum non conveniens. Such dismissal should rest on the lack of any significant contact with the forum and could be applied to sales cases under the same tests as used for actions generally. See Gulf Oil Corp. v. Gilbert, 330 U.S. 501 (1947); Kamas State Bank v. American Sur. Co., 285 F. Supp. 430 (W.D. Mo. 1967).

Federal courts may transfer "any civil action to any other district or division where it might have been brought" under 28 U.S.C. $\$ 1404$ (a) (1964). For the applicable law in that situation, see Van Dusen v. Barrack, 376 U.S. 612 (1964). See also Norwood v. Kirkpatrick, 349 U.S. 29 (1955) (power of federal courts under $\$ 1404$ is broader than the doctrine of forum non conveniens).

13 For a Code case involving a situation where the forum had no connection with the transaction (but in which there was no express agreement as to applicable law) see Associates Discount Corp. v. Cary, 47 Misc. 2d 369, 262 N.Y.S.2d 646 (Civ. Ct. 1965).

to A similar result could be reached through an application of the doctrine of renvoi. The local court could refer to the law of that state whose law was chosen by the parties as the "appropriate" law under the second sentence of UCC $\$ 1-105(1)$ (see n.70 infra), and then apply the whole Code of that state including its version of UCC $\$ 1-105(1) \cdot$ to uphold the parties' choice.
}

: UCC \$ $1-105$, Comment 1. 


\section{The Necessity of Agreement}

Thus far only one limitation on party autonomy has been considered-the reasonable relation requirement-and it has been argued that this limitation should operate only rarely to restrict the parties' choice of applicable law. Section 1-105, however, contains other limitations which may have a greater impact in policing choice of law clauses than will the reasonable relation limit. The Code states that the parties may agree as to the law which will govern their rights and duties. "Agree" is not defined, but certainly its meaning will be shaped by the definition of "agreement": "the bargain of the parties in fact . . ..'22 This bargain is to be found in the language the parties used and from circumstances surrounding the transaction, but simply because the choice of law clause is found in the fine print of a take-it-or-leave-it document does not mean that this was the bargain of the parties-that they agreed to the clause. ${ }^{23}$

The line between allowable pressure and forbidden overreaching, though a difficult one to draw, has been delineated by several courts. ${ }^{24}$ Using doctrines of contract interpretation, inadequacy of consideration, fraud, mistake, sharp bargain, and duress, courts attempt to preserve maximum freedom of contract without allowing the parties to destroy the process of agreement. The nature of the problem prevents the framing of fixed rules and requires courts to proceed on a case-by-case basis, working with general principles of what a consensual transaction ought to be.

Choice of law clauses in an agreement are no exception, and to the extent that such clauses have been agreed upon by the parties, the Code commands their enforcement. However, the court must not abdicate its task of determining whether the parties have agreed. This does not mean that the clause must have been discussed or that the complaining party must have read the clause. Rather, the clause must have been fairly enough obtained so that it ought to become a part of the total legal obligations of the parties, a determination which calls into play the doctrines of contract

\footnotetext{
$=\operatorname{UCC} \& 1-201(3)$

$=$ ( $)$. Henningsen v. Bloomfield Motors, Inc., 32 N.J. 358, 161 A.2d 69 (1960). See also Ehrenzweig, Adhesion Contracts in the Conflict of Laus, 53 CoLUM. L. REv. 1072 (1953).

"See Dawson, Economic Duress - An Essa! in Perspective, 45 Mich. L. Rev. 253 (1947); Schuchman, Consumer Credit by Adhesion Contracts, 35 Tt:SIP. L.Q. 125, 281 (1962).
} 
formation and interpretation by which all provisions of an agreement are tested.

One Code section which can be used to police party autonomy is 1-103:

Unless displaced by the particular provisions of this Act, the principles of law and equity, including the law merchant and the law relative to capacity to contract, principal and agent, estoppel, fraud, misrepresentation, duress, coercion, mistake, bankruptcy, or other validating or invalidating cause shall supplement its provisions. 25

This section gives direct Code authority for applying the contractual principles already discussed in determining the scope of the obligations arising out of the parties' agreement. Further, section 1-203, which imposes an obligation of good faith in the performance of every Code contract, can be used to strengthen an argument under 1-103.

For sales transactions the Code's unconscionability provision, 2-302, can form another base from which to test the enforceability of a choice of law clause. This section gives a court the power, which had been judicially developed long before this section was enacted, to refuse to enforce any clause found to be unconscionable. Such a finding may apply to the choice of law clause whenever the court believes that it was not agreed upon by the parties or that the law chosen had no normal connection with the bargain. ${ }^{26}$

25 UCC $\$ 1-103$.

$\approx$ There have been no reported cases in which the court has been asked to strike a choice of law clause on the basis that the clause or its method of procurement was unconscionable. There is, however, nothing unique about these clauses and general doctrines of unconscionability developed in other contexts should apply to agreements as to applicable law. The leading case is Williams v. Walker-Thomas Furniture Co., 350 F.2d 445 (D.C. Cir. 1965). Other cases which have applied this section include Home Improvement, Inc. v. Maclver, 105 N.H. 435, 201 A.2d 886 (1964) (court found that writing did not comply with local retail installment act and also that contract was unenforceable because buyers "were paying $\$ 1,609$ for goods and services valued at far less"); Toker v. Perl, 103 N.J. Super. 500,247 A.2d 701 (1968) (court found contract was induced by fraud and also that price paid for goods was exorbitant); Zabriskic Chevrolet, Inc. v. Smith, 99 N.J. Super. 44 l, 240 A.2d 195 (1968) (disclaimer of warranty clause held unenforceable, one ground being that the clause violated 2-302); Paragon Homes, Inc. v. Carter, 56 Misc. 2d 463, 288 N.Y.S.2d 817 (Sup. Ct.), affd per curiam, 295 N.Y.S.2d 606 (App. Div. 1968) (Court held unconscionable a clause by which the parties (a Maine corporatiou and a Massachusetts resident) agreed to submit to the jurisdiction of a New York court); and Frostifresh Corp v. Reynoso, 52 Misc. 2d 26, 274 N.Y.S. 2d 757 (Sup. Ct. 1967), rev'd in part, 54 Misc. 2d 119, 281 N.Y.S.2d 964 (App. Div. 1967) (sales techniques and price made contract unconscionable, and price term was re- 


\section{The Implied Agreement}

Although the parties' agreement with respect to applicable law has been assumed to be an express statement in a clause of the contract, the term "agree" would appear to be broad enough to include an implied agreement that the laws of a certain jurisdietion are to control the transaction. As previously indicated the word "agree" is not defined in the Code, ${ }^{2 \pi}$ but "agreement" is defined to "include the bargain of the parties as found in their language "or by implication from other circumstances." If If in a particular case the preponderance of contacts of a transaction are with one jurisdiction, and if the parties were (or should have been) familiar with that jurisdiction's laws, and if nothing is expressly stipulated as to choice of law, the circumstances clearly suggest that the parties implicitly agreed on that law as the applicable law. Nothing in the history of section 1-105 indicates that the drafters intended the word "agree" to mean anything more than the usual express choice of law clause, but an expanded reading of "agree" is not inconsistent with the language or policy of the Code..$^{2 y}$ Furthermore, pre-Code case law suggests such a reading. ${ }^{30}$

The easiest way for a court to avoid this problem of implied agreement would be to use the second sentence of 1-105 to apply the law of the jurisdiction with the preponderance of contacts, thereby considering that jurisdiction as having the "appropriate relation" to the transaction. (Such an interpretation of the second sentence of 1-105 is expanded below.) 1f, however, the court does not accept the suggested interpretation, the finding of an implied agreement under the first sentence of $1-105$ can be employed to

written by court). The Williams and American Home cases are analyzed in Lelf, Linconscionability' and the Code-The Emperor's New' Clause, 115 U. PA. L. Rev. 485 (1967).

${ }^{2 i}$ See note 22 supra and aceompanying text.

2x UCC \& 1-201(3).

20 But see Lyles v. Union Planters Nat'l Bank, 239 Ark. 738, 393 S.W.2d 867 (1965), which assumes that an express agreement is needed under UCC \& $1-105$.

30 E.g., Lauritzen v. Larsen, 345 U.S. 57 I (1953); Pinney v. Nelson, 183 U.S. 144 (1901); Prichard v. Norton, 106 U.S. 124 (1882); Grand v. Livingston, 4 App. Div. 589, 38 N.Y.S. 490 (1896). See also Seeman v. Philadelphia Warehouse Co., 274 U.S. 403 (1927): Green v. Northwestern Trust Co., 128 Minn. 30, 150 N.W. 229 (1914); Chinchilla v. Foreign Tankship Corp., 195 Misc. 895, 91 N.Y.S.2d 213 (1949).

The more recent "grouping of contacts" approach to choice of law can be explained on a presumed intent (or agreement) basis. Auten v. Auten, 308 N.Y. 155, 124 N.E.2d 99 (1954); Baffin Land Corp. v. Monticello Motor Inn, Inc., 70 Wash. 2d 893, 425 P.2d 623 (1967). 
reach a sensible result: the application of the most appropriate law for the transaction, considering the problem presented to the court.

\section{Impact on Third Parties}

Although the parties may agree as to the law which will govern their rights and duties, such agreement will not be binding on third parties to the transaction. This limitation on party autonomy is exemplified in some of the exceptions contained in subsection (2) of 1-105.31 Another of these exceptions is found in section 2-402, which provides that situs law is to be used to determine the rights of creditors of a seller who has retained possession of sold goods. Here third parties to the sale, the creditors, have intervened, and any choice of law rule agreed upon in the seller-buyer contract will have no impact on those third parties. Furthermore, most third parties will fit under one of the exceptions listed in 1-105(2), although those exceptions may not be exhaustive. The general tenor of the Code thus seems to indicate that no third party should be bound by a choice of law clause.

A case involving this third-party limitation on party autonomy is Industrial Packaging Products Co. v. Fort Pitt Packaging Int'l Inc. ${ }^{32}$ in which Fort Pitt assigned to a lender all payments due or to become due under a contract which Fort Pitt had with the United States. The contract of assignment contained a clause providing that the "agreement and performance thereof shall in all respects be governed by and in accordance with the laws of the state of New York." The Supreme Court of Pennsylvania stated that this clause was binding as between the parties but held that the rights of Fort Pitt's creditors were not affected by the choice of law agreement. "Otherwise, it would be possible for two parties to render nugatory as to third parties an Act of Assembly passed for the benefit of such third parties." ${ }^{33}$ The result of this case can be explained either on the basis that Article 9 transactions are expressly exempted from section $1-105^{34}$ or on the wording of 1105(1): The parties may agree as to the system of law which will govern their rights and duties.

\footnotetext{
"See note 3 supra and accompanying text.

$=399 \mathrm{~Pa} .643,161$ A.2d 19 (1960).

IId. at $647 ; 161$ A.2d at 21 .

" UCC \$ 1-105(2); UCC \$\$ 9-102, 103.
} 
Public Policy of the Forum

One limitation courts should not place on choice of law clauses in commercial transactions is the long-recognized principle that the public policies of the forum are not to be overridden by the application of foreign law. ${ }^{35}$ The proposed RESTATEMENT (SECOND), CoNfLICT OF Laws expands this public policy exception by providing that the law chosen by the parties will be used to determine the validity of a contract unless (among other things) "application of the chosen law would be contrary to a fundamental policy of the state which would be the state of the governing law in the absence of an effective choice by the parties. ${ }^{336}$

The Code contains no public policy exception to party autonomy in choosing applicable law, and none should be read in by the courts. It may well be that for the general area of conflict of laws some restrictions are needed on allowing parties to contract out from under local policies, but no such exception is required in commercial law where states have almost unanimousiy agreed on the basic Code policies. Although local Code variations have occurred which could be decisive in a particular case, these variations do not express some fundamental policy, "some deep-rooted tradition of the common weal, ${ }^{237}$ which should override legislative approval of the Code in general or of the doctrine of party autonomy in specific. There is no longer room in commercial law for a notion that because the rules applied to a particular problem vary in their detail, those details express some principle of strong local policy negating the parties' own choice of law. ${ }^{38^{\circ}}$

\section{The Appropriate Relation Test}

If choice of law problems arise in a transaction not covered by subsection (2) of 1-105 and if the parties have not designated the governing law, the forum's version of the Code "applies to

\footnotetext{
35 RESTATEMENT, CONFLICT OF LAWS $\$ 612$ (1934).

${ }^{26}$ Restatement (SeCOND), Conflict of LAws § 332a (Tent. Draft No. 6, 1960). There is practically no direct authority on the application of public policy to strike a choice of law clause. The only case found bearing on this problem is Fricke v. Isbrandtsen Co., $151 \mathrm{~F}$. Supp. 465 (S.D.N.Y. 1957).

$\rightarrow$ Loucks v. Standard Oil Co., 224 N.Y. 99, 111, 120 N.E. 198, 202 (1918).

as Cf. Hughes v. Fetter, 341 U.S. 609 (1951); Oltarsh v. Aetna Ins. Co., 15 N.Y.2d IIl, 204 N.E.2d 622, 256 N.Y.S.2d 577 (1965); Intercontinental Hotels Corp. v. Golden, 15 N.Y.2d 9, 203 N.E.2d 210, 254 N.Y.S.2d 507 (1964).
} 
transactions bearing an appropriate relation to this state. ${ }^{\text {'39 }}$ Some have read these words as a command to the forum to apply its local Code irrespective of how closely the facts of the transaction are connected with some other state-if the transaction bears an appropriate relation to the forum. ${ }^{40} \mathrm{~A}$ literal reading of the Code rule supports this conclusion, and such forum-orientation, reminiscent of Wachter's writings during the 19 th century, ${ }^{41}$ might even receive the partial support of Professor Ehrenzweig'2 and find a theoretical base in some of the earlier writings of Professor Currie. ${ }^{+3}$ Unfortunately, a strict "forum" approach could destroy predictability in multi-state commercial transactions because at the time the contract of sale is made, it may be impossible to predict the location of the forum for potential litigation. It is, however, too late to think seriously about amending the Code's general choice of law rule. Persuading more than 50 legislatures to amend section 1105 is probably impossible. Instead, the task must be less ambitious: to determine the meaning of the words in the Code rule and how those words can be used, and in this respect, the history of $1-105$ is particularly helpful.

\section{History of the Appropriate Relation Test}

The choice of law provision in the 1952 version of the Code was not stated in terms of an appropriate relation. Rather the provision, in addition to providing for party autonomy, specified certain minimal contacts which, if found to exist, would provide a basis for the application by the forum of its version of the Code to transactions having interstate connections. For example, Article 2 on Sales was to be applied if:

1. The contract was made in the state, or

2. The offer was made in the state, or

ज UCC \& 1-105(1).

10 Cf. Weintraub, Choice of Law in Contract, 54 lowa L. Rev. 399, 418 (1968); Weintraub, Choice of Law for Products Liability: The Impact of the Uniform Conmercial Code \& Recent Developnents in Conflicts Analysis, 44 TExAs L. REv. 1429, 1436-37 (1966). One of the authors of this article is guilty of such a public statement, tor which he now recants. Nordstrom, Choice of Law and the Uniform Commercial Code, 24 Oнго ST. L.J. 364 (1963).

"Wachter, On the Collision of Private Laws of Different States, 13 Ast. J. CoMp. L. 417 (1964).

32 A. Ehrenzweig, Conflict of Laivs 307-46, 464 (1962).

"Compare Currie, Notes on Methods and Objectives in the Conflict of Laws, 1959 DuKE L.J. 171 with Currie, The Disinterested Third State, 28 LAw \& CONTEMP. Pros. 755 (1963). 
3. The acceptance occurred in the state, or

4. The contract was to be performed or completed wholly within the state, or

5. The contract was to be performed or completed in part within the state, or

6. The contract related to or involved goods "which are to be or are in fact delivered, shipped or received" within the state, or

7. The contract involved " $a$ bill of lading, warehouse receipt or other document of title which is to be or is in fact issued, delivered, sent or received" within the state, or

8. The contract "is an application or agreement for a credit made, sent or received within this state, or involves a credit issued in this state or under which drafts are to be presented in this state or confirmation or advice of which is sent or received within this state, or involves any negotiation within this state or a draft drawn under a credit," or

9. The transaction occurred within the state."

Since the phrases were connected with an "or," the existence of any one of these contacts would suffice to make the local Code applicable to the sales transaction.

A desire to have the Code applied to as many transactions as possible apparently motivated the drafters to formulate the choice of law provision in the manner they did. When first promulgated, it was not expected that the Code would receive anything approaching unanimous acceptance for years or perhaps decades, and for a period of about five years it appeared that the Code might never receive approval except from a handful of states..$^{15}$ Nevertheless, the drafters firmly believed that the Code was a marked improvement over prior law and ought to be applied to as many transactions as possible..$^{46}$ One way to accomplish this goal was to seek further adoptions; this they did through amendments

\footnotetext{
"UCC \$1-105 (1952 version).

is Between 1952 and 1960 only five states adopted the Code. These were Pennsylvania (1953), Massachusetts (1957), Kentucky (1958), Connecticut (1959), and New Hampshire (1959). During the next seven years the Code was enacted in 44 states, the District of Columbia, and the Virgin lslands.

${ }^{15}$ Although the comments to the 1952 Code did not expressly state that this was the reason for adopting a forum-oriented rule, this motive was acknowledged in the 1958 and 1962 comments: "Application of the Code in such circumstances may be justified by its comprehensiveness, by the policy of uniformity, and by the fact that it is in large part a reformulation and restatement of the law merchant and of the understanding of a business
} 
designed to meet justified criticisms which had been raised.". Another approach was to encourage the application of adopted Codes to as many commercial transactions as could constitutionally be reached, and this the drafters accomplished by selecting a choice of law provision which permitted the forum to apply the Code to all transactions in which there was at least a minimal connection between the forum and the transaction. If the Code was adopted in states having a sizeable number of commercial transactions, Code policies would govern a significant portion of the country's commerce which, in turn, could lead to further Code adoptions.

There were immediate objections to the 1952 version of $1-105.48$ Some attacked the policy which formed the basis of the section; others questioned the constitutionality of the rule. The Code approach was strikingly different from both the vested rights theory, ${ }^{49}$ which was still followed by most courts, and the newer approaches to choice of law problems. Critics who objected to the Code rule on policy grounds focused on the forum shopping encouraged by the Code. ${ }^{50}$ Forum shopping was a definite

community which transcends state and even national boundaries." UCC $\S 1-105$, Comment 3.

Professor Goodrich denies that a forum-oriented rule was selected because of a "primitive view that a state will resolve all legal problems with foreign contacts solely according to its own laws because it deems its law the best or most enlightened." Goodrich, Conflict Niceties \& Commercial Necessities, 1952 WISC. L. Rev. 199, 202. He suggests the explanation, not incompatible with that set out above, that the rule was adopted to insure that the law of a single state governed the entire transaction. Id. at 202. This was not the case under pre-Code law. See Restatenent, CoNflict of Laws $\$ \$ 332,358$ (1934).

"The 1952 official draft was revised in 1957 and supplemented in 1958. As revised, the Code was printed in a 1958 official Text. Further revisions resulted in a 1962 Official Text. Additional amendments were suggested in 1966.

"* One of the carliest objections to the pre-1952 drafts came from a number of teachers of Conflict of Laws who met in 1949 and passed a resolution which stated that UCC $\$ 1-105$ (in both forms which they reviewed) "is unwise and should be omitted from the Code." This resolution is reproduced in Rheinstein, Conflict of Laws in the Uniform Commercial Code, 16 LAW \& CONTEMP. Prob. 114, 115 (1951). See also Freund, Analysis of Conflicts of Law Provisions of Section l-105, 1955 N.Y. LAw Revision Cons'N REP. (vol. 1) 175; Smith, Conflicts and Chaos or Contract and Uniformity: The Uniform Commercial Code 2 U.KAN. L. REv. 11 (1953).

${ }^{19}$ For a discussion of the vested rights theory, see E. Stisison, ConfLict of LAws 80 (1963); Cheatham, American Theories of Conflict of Laws: Their Role and Utility, 58 Harv. L. Rev. 361, 379-85 (1945). See also 1 J. Beale, Treatise on the Conflict of LAws $§ 5.4$, at 53 (1935).

5 Stumberg, Commercial Paper and the Conflict of Laws, 6 VAND. L. Rev. 489, 503 (1953). The use of choice of law rules to prevent the accident of the forum from determining 
possibility, especially in areas such as open price agreements where the Code radically changed prior law.

Those who attacked the Code choice of law provision on constitutional grounds maintained that the rule, in attempting to make the Code applicable to transactions having only the slightest factual connection with the forum, violated the due process clause of the fourteenth amendment. To support their argument the critics cited Home Insurance Co. v. Dick, ${ }^{51}$ a 1930 case in which the Supreme Court in emphasizing the absence of contacts between the forum state, Texas, and the transaction, specifically discounted the fact that the forum was the permanent residence of one of the parties and overturned an application of forum law. According to the Court, "Texas was . . . without power to affect the terms of contract so made. lts attempt to impose a greater obligation than that agreed upon and to seize property in payment of the imposed obligation violates the guaranty against deprivation of property without due process of law." 52 The critics of the Code contended that the Court had never relinquished all controls over state choice of law, and that the Code's contacts, like the contact in Dick, were constitutionally insufficient. ${ }^{53}$

Drawing upon policy arguments, defenders of the 1952 version of 1-105 contended that there was a need for one law to apply to an entire transaction; and that the Code, which was based in large part on a "reformulation and restatement of the law merchant and of the understanding of a business community which transcends state and even national boundaries, "25s should be that law. The Code's policies were to be preferred over non-Code doctrines, and the application of the Code to all aspects of commercial transactions would promote simplicity and facilitate commerce.55 With respect to the constitutional objections to the Code, the supporters suggested that Dick had been impliedly overruled by

the outcome of the litigation has been expressed in several non-contract cases as well. See. e.g., Lauritzen v. Larsen, 345 U.S. 571 (1953). See generally Linn v. Employers Reinsurance Corp., 392 Pa. 58, 139 A.2d 638 (1958); Goodrich, Public Policy in the Law of Conflicts, 36 W. VA. L.Q. $156(1930)$.

"21 281 U.S. 397 (1930).

s. Id. at 408.

$\because$ Rheinstein, Conflict of Laws in the Uniform Commercial Code, 16 LAw \& ContentP. Prob. 114, 120 (1951).

s UCC \& 1-105, Comment 3.

si Goodrich, supra note 46, at 202. 
later decisions which appeared to return to the states the formulation of choice of law rules. ${ }^{56}$ If not overruled, Dick could be read as holding only that the forum could not apply its law when the only connection with the transaction was that the suit was brought there. The Code clearly required something more than that connection.

These arguments were never resolved. The 1958 version of the Code contained a new rule-that currently found in section 1-105. The relationship of the present "appropriate relation" test to the prior enumeration of contacts is not clear. It is arguable that "appropriate relation" is no more than a generic term for the more specific details of the 1952 version. If this is the case, the arguments over the 1952 rule apply equally to the present formulation of 1-105. On the other hand, it can be contended that the new test, in response to the criticism of the 1952 version, was designed to require a closer connection between the facts and the forum jurisdiction. . $^{57}$ third, and most likely, explanation is that the drafters intended to affirm party autonomy and leave to the courts the task of deciding choice of law problems on a case-bycase basis whenever the parties have not selected the law to govern their transaction.

\section{The Comments and the Cases}

Little assistance as to the scope of an appropriate relation or the connection between the 1952 and present rules is found in the Comments, which merely state that the determination of "what relation is "appropriate' is left to judicial decision," while reiterating that courts deciding cases under the Code are not bound by pre-Code conflicts cases.$^{58}$ The only relations excluded by the Comments as "not appropriate" are those in which the forum's sole contact is its status as forum, and where the parties clearly contracted with reference to some other law; for example, where the law of the places of contracting and performance are the same but contrary to forum law.

$\approx$ E.g., Crider v. Zurich Ins. Co., 380 U.S. 39 (1965); Clay v. Sun Ins. Office, Ltd., 377 U.S. 179 (1964). See Comment, The Uniform Commercial Code and Conflict of Laws, 9 A.s. J. CoMP. L. 458 (1960).

${ }^{5}$ See Cullen, Conflict of Laws Problems Under the Uniform Commercial Code, $48 \mathrm{KY}$. L.J. 417, 425 (1960); cf. Reese, The Uniform Conmercial Code and its Application in the Non-Code States, 15 BAYLOR L. Rev. 291, 301 (1963). 
Thus far appellate courts have not been required to consider the full meaning of an "appropriate relation." In Skinner v. Tober Foreign Motors, Inc., ${ }^{59}$ the seller of an airplane was a Massachusetts corporation with its principal place of business in Massachusetts. Both negotiation and execution of the contract took place in Massachusetts, and delivery was made in that state. Shortly thereafter the airplane developed engine trouble, and the buyers, being financially unable to keep up the payments and at the same time repair or replace the engine, offered to return the airplane in cancellation of the agreement. Instead, the seller orally agreed to reduce the monthly payments so that the buyers could proceed with the repairs. While the buyers, residents of Connecticut, were meeting their obligations under the oral agreement-but in default of the written agreement-the seller took the airplane from Connecticut (where it was kept) and returned it to Massachusetts. The buyers brought suit against the seller in a Massachusetts court, seeking equitable replevin or damages. Affirming an award of damages for the buyers, the court pointed out that there was no evidence as to where the oral modification was made and held that Massachusetts law applied because the transaction bore an appropriate relation to that state. Since the Code (then effective in Massachusetts but not in Connecticut) dispensed with the requirement of consideration to support a contractual modification, the buyers were entitled to recovery.

In contrast to Skinner, in Park County Implement Co. $v$. Craig $^{60}$ the only transactional connection with the non-Code state was that the buyer took delivery of the goods there. All other contacts were with the Code state (Wyoming) including the residence of the parties, the place where the goods were ordered, and the place to which the goods were taken after delivery. The seller sued the buyer in Wyoming for the price after the goods were destroyed by fire. The court held that the transaction bore an appropriate relation to Wyoming and that the Wyoming Code determined whether there had been an acceptance of the goods. The relation to the non-Code state was described as "minor." 61

\footnotetext{
ss UCC \$ $1-105$, Comment 3.

s9 345 Mass. 429,187 N.E.2d 669 (1963).

co 397 P.2d 800 (Wyo. 1964).

61 Other Code cases include Silver v. Sloop Silver Cloud, 259 F. Supp. 187 (S.D.N.Y. 1966) (place of making and payment); Lyles v. Union Planters Nat'l Bank, 23 Ark. 738, 393
} 


\section{The Meaning of "Appropriate Relation"}

The basic reason for including a forum-oriented choice of law rule in the Code-the maximization of the number of commercial transactions which would be subject to the Code's policies-assumes that only a few states have adopted the Code and that most of the cases tried in a Code state will involve' some factual connections with non-Code states. Today, however, all but one of the states have adopted the Code, and there is no longer a tug-of-war between the enlightened answers of the Code and the older answers it displaced. Except in international transactions, almost all commercial choice of law problems will arise between Code states; the goal which motivated the selection of the forumoriented choice of law rule, the wide-spread use of the Code in solving commercial problems, has been achieved through legislative acceptance of the Code. The choice of law problem continues, nevertheless, in those areas in which the adopted statutes or their interpretations differ.

Fortunately, the test chosen by the drafters, that the relation must be appropriate, gives the courts freedom to develop rational choice of law rules and apply them to commercial transactions. A relation which was appropriate when the problem was whether to apply a newly drafted comprehensive code or the law of a non-Code state does not necessarily continue to be appropriate when all states involved have the same basic legislation. In the early cases, a court could justify finding an overriding policy supporting Code application because it represented a "reformulation and restatement of the law merchant and the understanding of a business community which transcends state and even national boundaries." ${ }^{2}$ In short, the Code could have been applied simply because it came the closest to protecting the justified expectations of the businessmen involved. However, that reason for adopting a forumoriented approach disappears once all the states have adopted the Code. The appropriate relation which requires application of a particular state's law can now be redefined in light of the policies underlying the state's conflict rules. Thus a court is free to develop further choice of law policies and to refine the process which it began in cases like Skinner and Park County.

S.W.2d 867 (1965); Atlas Credit Corp. v. Dolbow, 193 Pa. Super. 649, 165 A.2d 704 (1960) (applying 1952 text of Code).

$\approx$ UCC \$ 1-105, Comment 3. 
Although it is not possible to review all the policies which can be promoted through choice of law rules, it should be suggested at this point that 1-105 is flexible enough to reach at least these goals in cases presenting choice of law problems: $: 3$

1. Separate the true conflicts cases from the false ones. In some interstate transactions there is no necessary conflict among the laws involved-even though there is a difference in the language of the Code sections as adopted by the various states. For example, suppose that State A has adopted the 1962 official version of section 2-318 which extends warranties to the family, household, and guests (in the home) of the buyer, but has refused to accept the invitation of the Comments to increase the number of persons within the protected class. ${ }^{64}$ One reason for not extending 2-318 could be a policy of supporting and promoting manufacturing in State A by limiting manufacturers' liabilities for goods sold within the state. Suppose, however, that State B has amended its version of 2-318 to extend warranties to any person who reasonably might be expected to be affected by the goods-even though they are not within the family, household, or guest classification adopted in State A. ${ }^{65}$ Here the policy might be one of insuring that injured persons, including at least State $B$ residents, will have funds to pay doctor and hospital bills and will not become charges upon the welfare taxes of State B. ${ }^{6}$ Suppose further that a car was manufactured and sold to Buyer in State B. Buyer and his employer (both residents of State B) attended a convention in State A where the employer, while a passenger in Buyer's car, was injured because of a defective part in the automobile.

Under these facts a court could reasonably conclude that there is no conflict in the policies underlying the different versions of 2-

- See Weintraub, The Contracts Proposals of the Second Restatement of Conflict of Laws-A Critique, 46 Iowa L. Rev. 713, 713-19 (1961). These considerations were originally set out in Cheatham and Reese, Choice of the Applicable Law, 52 Cotum. L. Rev. 959 (1952). See also Currie, Notes on Methods and Objectives in the Conflict of Laws, 1959 Duke L.J. 171; Traynor, is This Conflict Really Necessar!?, 37 Texas L. Rev. 657 (1959).

${ }^{83}$ See. e.g.. Hochgertel v. Canada Dry Corp., 409 Pa. 610, 187 A.2d 575 (1963); Marcus v. Spada Bros. Auto Serv., 41 Pa. D. \& C. 2d 794 (Phila. County Ct. 1967).

ws See, e.g., VA. CODE ANN. \$ 8.2-318 (1965). For two other expanded versions of UCC \$ 2-318 see Permanent Editorial Board for the Uniform Comimercial Code, Rep. No. 3 (1966). California and Utah omitted the section altogether.

${ }^{25}$ See Currie, Survival of Actions: Adjudication versus Automation in the Confllat of Laws, 10 Stan. L. Rev. 205 (1958). 
318.67 Since the car was not manufactured in State A, State A's policy of promoting State A manufacturing will not be harmed by extending the warranty protection to the employer. State B's policy of providing added protection to its citizens through an expanded warranty provision will be advanced by applying State B's version of the Code. Thus, if such a problem is presented to a court in State A, that court ought to use the "appropriate relation" test to sort out the policies underlying the sections of the apparently conflicting Codes and, in a proper case, determine that it is not appropriate to apply State A's version of 2-318 because the relation of the parties to State A under these facts does not present a case in which the policies underlying State A law have any concern. Furthermore, this result should not be altered despite the fact that Buyer may have mailed the purchase order from State A while Buyer was on a State A vacation, or that the automobile was delivered from State B to Buyer while he was temporarily in State $A$, or because Buyer had arranged for credit with a State A bank-all factual connections which would have required application of State A's Code under the 1952 version of 1-105.

2. Provide a rational basis for the solution of the true conflicts case. A so-called "true" conflicts case can be presented by returning to the automobile purchase case above but reversing the states of the purchase and the injury. Had Buyer purchased the automobile in State A from a State A manufacturer, and had the injury to the employer occurred while the parties were in State B, State A's policy of promoting manufacturing by limiting the number of persons who can recover for injuries caused by defective goods collides with State B's policy of p'roviding compensation for injured plaintiffs-especially if the employer and Buyer are residents of State B. It is this kind of case which presently is being subjected to critical analysis by judges and writers. $^{68}$ As yet no single solution has been agreed upon by the

\footnotetext{
if This type of analysis is used on the problem of the applicable statute of frauds in Bernkrant v. Fowler, 55 Cal. 2d 588, 360 P.2d 906, 12 Cal. Rptr. 266 (1961). See also McCrossin v. Hicks Chevrolet, Inc., 248 A.2d 917 (D.C. Ct. App. 1969).

6x See A. von mehren \& D. Trautisan. The law of Multistate Problems 76-79 (1965), and the reference to the articles by Professor Currie, especially Currie, The Constitution and the Choice of Law: Governmental Interests and the Judicial Function, 26 U. Chi. L. Rev. 9 (1958). See also A. Ehrenzweig, Conflict of Laivs 309-26, 247-54 (1962); Baade, Counter-Revolution or Alliance for Progress? Reflections on Reading Cavers. the Choice-of-Law" Process, 46 TexAS L. Rev. 141 (1967). For a "true" conflicts case in
} 
courts, nor is one suggested in this article. 1 t merely is urged here that the "appropriate relation" test is sufficiently broad to enable courts of Code states to continue their development of choice of law principles and not feel bound to apply forum law in a commercial transaction simply because they find a minimum contact between the facts of the transaction and the forum. For example, to the extent that the forum court believes that true conflicts cases ought to be solved by reference to the law of the state with the most significant connection with the transaction, ${ }^{60}$ only a slight wrench of Code language is required to classify this connection as the "appropriate relation" and to apply that policy to a section 1-105 transaction.70

3. To the extent possible, minimize the intpact which the accident of the forum has in determining the outcome of the litigation. Certainty and predictability, worthy goals in commercial transactions, will be unobtainable as long as forum law is applied simply because that forum has some minimal contact with the underlying transaction. On some occasions this loss is unnecessary. For example, in the false conflicts case discussed under 1 , supra, it was concluded that the assumed policies indicated that it was not appropriate in such a case for the forum to apply its version of the Code in framing a rule of decision. Such a conclusion, however, is negative in its impact; it says only that the forum Code should not be applied. It can further be suggested that the forum court should frame a rule of decision patterned after that version of the Code whose policies will be promoted by the solution of the legal problems presented by the factual pattern of the specific litigation-in the assumed case, this would be the law of State B.

torts, see Kilberg v. Northeast Airlines, inc., 9 N.Y.2d 34, 172 N.E.2d 526, 211 N.Y.S.2d 133 (1961).

${ }^{69}$ See Auten v. Auten, 308 N.Y. 155, 124 N.E.2d 99 (1954); Baffin Land Corp. v. Monticello Motor Inn, Inc., 70 Wash. 2d 893, 425 P.2d 623 (1967); RestateneNt (SECOND), CoNfeict of Laws \$ 332 (Tent. Draft No. 6, 1960). For a discussion of ádditional approaches to choice of law problems, see D. CAvers. THe CHOICE-OF-Law Process 59-87, 114-38 (1965).

${ }^{30}$ Associates Discount Corp. v. Cary, 47 Misc. 2d 369, 262 N.Y.S.2d 646 (Civ. Ct. 1965), may illustrate such a wrench, although the decision probably rests on UCC $\S 9-103$. The statement in the text may be supported by the suggestions made in Ideal Structures Corp. v. Levinc Huntsville Dev. Corp., 396 F.2d 917, 921.923 (5th Cir. 1968). Unfortunatcly, the court in this non-Code case was not free to pursue the suggestion since it was bound by the state choice of law rule. See also Klaxon Co. v. Stentor Elec. MIg. Co., 313 U.S. 487 (1941). 
Such application minimizes the importance of the forum without sacrificing any local policy. Likewise, the suggested reading of 1$105(1)$ in the true conflicts case (see 2, supra) insulates a commercial transaction from the happenstance of the forum to the same extent that the forum's general choice of law rules seek this goal.

Admittedly, this suggested interpretation of the appropriate relation test of 1-105(1) takes some liberty with the Code's terse language. However, 1-105 was drafted for situations in which it was assumed that only a few states had the Code, and the drafters thus intended that its comprehensive restatement of the law merchant have the widest possible application. ${ }^{71}$ Now, following the Code's wide adoption, the "appropriate relation" test can take on new meaning, lose its forum-oriented direction, and promote rational choice of law results.

\section{CONCLUSION}

The nearly unanimous acceptance of the Uniform Commercial Code has eliminated many of the choice of law problems which once existed in interstate commercial transactions. Although some teachers of Conflict of Laws may mourn the demise of these problems, the practicing lawyer and his business clients have reason to rejoice. Considerable certainty has replaced extensive confusion. There remain, however, areas of commercial law in which legislatures and courts in one state promote policies different from those of the legislatures and courts in other states. The Code, with one of the most comprehensive choice of law statutes yet enacted,

\footnotetext{
"The conclusion that the drafters intended to state a forum-oriented rule only during the time that the Code was effective in a few jurisdictions is supported by the terse command of UCC \$ 1-105: "Failing such agreement this Act applies to transactions bearing an appropriate relation to this state." No express provision was made for the case in which there existed no appropriate relation to the forum. Should a court which is a disinterested forum, providing it decides not to dismiss the case under some variation of the forum non conveniens doctrine, (1) return to pre-Code choice of law rules resting on place of making or place of performance or whatever, or (2) seek out and apply the policies underlying the appropriate relation test? The authors of this article contend that only the second alternative is reasonable. The drafters were expressing a desire that the appropriate law be applied. Now that all (or nearly all) of the states have the Code, the appropriate law need not be tied to the forum. Such a reading of UCC $\$ 1-105$ is also supported by Comment 2 to UCC $\$ 1-105$ : "Where there is no agreement as to the governing law, the Act [not this version of the Act] is applicable to any transaction having an "appropriate' relation to any state which enacts it." See also D. Cavers. The Choice-Of-Laiv Process 233-40 (1965).
} 
seeks to retain certainty for the parties by allowing agreement as to the law which will govern the transaction, subject only to the requirement that the transaction have a "reasonable relation" to the state whose laws are chosen-often a requirement of little impact because businessmen simply do not choose to have their transactions governed by laws that are strange to them. Undoubtedly, the portion of the statutory grant of party autonomy which will have the greatest impact on policing choice of law clauses is the requirement that the parties "agree" on the clause. Here, common law contract notions of subjective and objective mutual assent will continue to play their role.

The remaining cases, those in which the parties have not agreed on applicable law, will present the hardest problems of statutory interpretation. Courts must seek out something that the Code has called an "appropriate" relation. On occasion this will be difficult but a court need not compound the difficulty by believing that the Code choice of law rules present a different process from that used in other areas of conflict of laws. The "appropriate relation" test frees the court from the narrow tests of prior Code versions such as place of making or performance and allows it to adopt choice of law rules resting on rational foundations. Furthermore, the Code may someday form the base from which choice of law principles can be enunciated in non-commercial areas. 